Ann. Biol. anim. Bioch. Biophys., 1979, 19 (4 B), 1231-1237.

\title{
$H-Y$ antigen in the mammalian female
}

\author{
par S. S. WACHTEL
}

\author{
Memorial Sloon-Ketfering Cancer Center \\ 1275 York Av., New York, New York 10021. \\ and Deport. of Pediatrics, N.Y. Hospital-Cornell Medical Center. \\ New York, N.Y. 10021 USA.
}

\begin{abstract}
Summary. Presence of $\mathrm{H}-\mathrm{Y}$ antigen does not always indicate presence of testes. When disseminated $\mathrm{H}-\mathrm{Y}$ antigen fails to engage its receptor, the undifferentiated mammalian gonad becomes an ovary. In man this may degenerate, thereby giving rise to the syndrome of $46, \mathrm{XY}$ « gonadal dysgenesis $»$ in- $\mathrm{H}-\mathrm{Y}^{+}$phenotypic females.

Our recent detection of $\mathrm{H}-\mathrm{Y}$ in polled intersex goats and in a human family of « recessively-determined 》 $X X$ males and their mothers implies that $\mathrm{H}-\mathrm{Y}$ loci may also act as recessive genes. $\mathrm{H}-\mathrm{Y}$ loci may therefore be viewed as a consortium of testis-determining elements, translocation events giving rise to both dominant and recessive modes of male sex determination, according to the quantity (or quality) of $\mathrm{H}-\mathrm{Y}$ elements transferred. Expression of $\mathrm{H}-\mathrm{Y}$ in the fertile female is consistent with this scheme as the particular antigenic specificities detected might represent a functionally insignificant portion of the testisdetermining $\mathrm{H}-\mathrm{Y}$ complex.
\end{abstract}

\section{Introduction.}

The role of gonadal hormones in sex differentiation has been elucidated by the classical studies of Jost $(1953,1961,1970)$; when rabbit feluses are castrated they become females regardless of genetic sex. Moreover, in androgen insensitive mammals with a $Y$-chromosome, the gonads become testes (presumably under the influence of the $Y$ ) and the testes secrete testosterone, but further differentiation is female (presumably because of mutation of the androgen receptor; see discussion in Wilson, 1978). Thus in the absence of testicular hormones, or $\mathbf{n}$ cases of insensitivity to testicular hormones (or their metabolites), the mammalian $X Y$ embryo becomes a female, and this implies that androgens actively impose maleness by diverting the fetus from an inherent pathway of female development. Accordingly the pivotal sex-determining role of the mammalian $Y$-chromosome is limited to the differentiation of the festis.

Yet $X X$ embryos may develop testes and $X Y$ embryos may develop ovaries, so it is not the $Y$-chromosome per se that induces testicular differentiation, but another 
factor, normally associated with the $Y$. We have proposed that this « new " factor is the so-called $\mathrm{H}-\mathrm{Y}$ (histocompatibility- $\mathrm{Y}$ ) antigen, a cell surface component discovered with the observation that male skin grafts are rejected by females within certain highly inbred strains of the mouse. Our proposal that $\mathrm{H}-\mathrm{Y}$ antigen induces the undifferentiated mammalian gonad to become a testis (Wachtel et al., 1975) is based on the following empirical considerations :

(1) Widespread phylogenetic conservation : serologically defined $H-Y$ antigen (identified by antiserum from male-grafted female mice) is present in cells from males of every mammalian species tested.

(2) Presence in sex-reversed mice : $H-Y$ occurs in $X X$ male mice «sex-reversed " by the autosomal dominant gene, $\mathrm{S} x \mathrm{r}$, indicating close association or identity of testis determining and $\mathrm{H}$-Y-determining loci (Bennett et al., 1977).

To evaluate our proposal we studied expression of $\mathrm{H}-\mathrm{Y}$ in a variety of subjects whose gonadal sex did not correspond to their karyotype or secondary sex phenotype, and in patients with structural or numerical abnormalities of the Y-chromosome. In every case, $\mathrm{H}-\mathrm{Y}$ antigen expression was correlated with development of at least rudimentary testes. Thus for example $H-Y$ was present in $X X$ human males and true hermaphrodites as well as in $\mathrm{S} \times \mathrm{r} /-, \mathrm{XX}$ male mice, and $\mathrm{H}-\mathrm{Y}$ was present in androgeninsensitive females with testicular feminization syndrome; in contrast, $\mathrm{H}-\mathrm{Y}$ was absent in fertile $X Y$ females of the wood lemming (Silvers and Wachtel, 1977).

In this paper I shall review more recent evidence showing : (1) that presence of $\mathrm{H}-\mathrm{Y}$ antigen is not always an indicator of testicular differentiation, (2) that expression of $\mathrm{H}-\mathrm{Y}$ need not preclude fertility in the mammalian female, and (3) that $\mathrm{H}-\mathrm{Y}$ genes comprise a family of testis-determinants coding for a system of distinct antigenic specificities.

\section{Materials and methods.}

Expression and non-expression of $\mathrm{H}-\mathrm{Y}$ were determined serologically : sera from male-sensitized C57BL female mice were tested and pooled and the pools divided into four parts : one part was unabsorbed (untreated), one part was absorbed with cells from normal females $\left(\mathrm{H}_{-} \mathrm{Y}^{-}\right)$, and one part was absorbed with cells from normal males $\left(\mathrm{H}-\mathrm{Y}^{+}\right)$; one part was absorbed with cells from the subject being tested. Assignment of $\mathrm{H}-\mathrm{Y}$ phenotype was based on the ability of cells from the subject to absorb $\mathrm{H}-\mathrm{Y}$ antibodies relative to the ability of cells from normal $X Y\left(\mathrm{H}-\mathrm{Y}^{+}\right)$males. Positive absorption, indicating presence of $\mathrm{H}-\mathrm{Y}$ antigen on absorbing cells, was manifested as a decreased reactivity of absorbed sera in any of several assays including the sperm cytotoxicity test, the mixed hemadsorption-hybrid antibody (MHA.HA) test, and the Protein-A hemadsorption (PA-SRBC) test. Positive absorption resulted in proportionately fewer cells killed in the sperm cylotoxicity test or in fewer cells labelled in the MHA.HA and PA-SRBC tests. For details of the testing procedures, see : sperm cytotoxicity test, Goldberg ef al. (1971) ; MHA. HA test, Koo, Boyse and Wachtel (1977) ; PA-SRBC test, Koo and Goldberg (1978). 


\section{Results and Discussion.}

The $X Y$ female wood lemming condition is inherited as an $X$-linked trait (Fredga ef al., 1977). It follows that a gene on the $X$-chromosome of this species can suppress testicular (and $\mathrm{H}-\mathrm{Y}$ ) determinants. And in view of the extreme evolutionary consevatism of the mammalian $X$-chromosome, it follows that a similar gene exists in man (see discussion in German ef al., 1978). Apparently in humans two $X$ chromosomes $(46, X X)$ are required to sustain normal ovarian differentiation. Human embryos with the 45, XO karyotype (Turner syndrome) develop ovaries initially, but these regress and are represented at the time of birth by undifferentiated streaks. In this respect 46, XY embryos resemble 45, XO embryos ; in cases of deletion or mutational suppression of the testis-determining region of the $Y$, the gonads of these embryos initially become ovaries, but the ovaries degenerate, thereby giving rise to the syndrome of $X Y$ « pure gonadal dysgenesis » (Sternberg, Barclay and Kloepfer, 1968 ; Espiner et al., 1970). We are currently studying $\mathrm{H}-\mathrm{Y}$ antigen expression in two human sibships representing possible cases of $X$-linked gonadal dysgenesis. Early indications are that $\mathrm{H}-\mathrm{Y}$ expression is absent or considerably reduced in the probands. Thus it would appear that in man as in the wood lemming, suppression of $\mathrm{H}-\mathrm{Y}$ leads to aberrant development of the " genetic 》 testis.

Nevertheless presence of $\mathrm{H}-\mathrm{Y}$ need not signify testicular differentiation. We have also observed cases of pure gonadal dysgenesis in 46, XY phenotypic females characterized by the $\mathrm{H}-\mathrm{Y}$ positive cellular phenotype (Dorus et al., 1977). This indicates either (1) that $\mathrm{H}-\mathrm{Y}$ is not testis-determining, or (2) that $\mathrm{H}-\mathrm{Y}$ itself is not sufficient for masculinization of the gonad. We prefer the latter interpretation, as the association of $\mathrm{H}-\mathrm{Y}$ antigen and testicular organogenesis would seem more than coincidental at this juncture. (Perhaps the best evidence to date for a testis-determining role of $\mathrm{H}-\mathrm{Y}$ was provided recently by the experiments of Ohno, Nagai and Ciccarese (1978) and Zenzes ef al. (1978) who showed that dispersed Sertoli cells of the neonatal testis reaggregate in culture to form ovarian follicle-like structures when treated with specific $H-Y$ antibody, whereas untreated cells reaggregate to form tubules.)

How can we explain gonadal dysgenesis in $46, X Y$ embryos that are $\mathrm{H}_{-} \mathrm{Y}^{-}$and the same condition in 46, $\mathrm{XY}$ embryos that are $\mathrm{H}_{-} \mathrm{Y}^{+}$? Based on our detection of $\mathrm{H}-\mathrm{Y}$ in the gonads of the bovine freemartin fetus (Ohno et al., 1976), and in $X X$ testicular cells of the $X X / X Y$ chimeric male mouse (Ohno ef al., 1978), we have proposed that $\mathrm{H}-\mathrm{Y}$ antigen is disseminated and bound by receptors on the surfaces of both $X X$ and $X Y$ gonadal cells (Muller et al. (1978) have now reported binding of " exogenous » $H-Y$ in the rat). According to this notion, $X Y$ gonadal dysgenesis and female phenotypic development would ensue after failure of $\mathrm{H}-\mathrm{Y}$ synthesis, dissemination or binding. In the latter case (failure of dissemination or binding) somatic cells of the proband would type $\mathrm{H}-\mathrm{Y}^{+}$.

\section{$H-Y$ antigen in the fertile female}

Intersexuality is common among certain breeds of the dog. In fact familial occurrence of $X X$ male syndrome has been documented in cocker spaniels, implying 
segregation of testis-determining $\mathrm{H}-\mathrm{Y}$ loci that are not on the $\mathrm{Y}$-chromosome in this breed. Recently we studied a family of cocker spaniels in which $\mathrm{H}-Y$ genes were present in an $X X$ male pup and in his $X X$ mother. But histologic examination of the mother's gonads revealed presence of testicular tubules as well as ovarian follicles bilaterally; the mother was a true hermaphrodite (Selden ef al., 1978). Subsequent karyotypic analysis revealed an apparent $Y$-to-autosome translocation in the $X Y$ sire of the true hermaphrodite. It seems that he carried two $Y$-chromosomes, and the $Y$-toautosome translocation is what he had transmitted to his true hermaphrodite daughter and she to her $X X$ male pup. These data imply that $X X$ true hermaphroditism and $X X$ male sex-reversal share a common etiology, that both conditions are associated with anomalous transmission of at least a portion of the $Y$-chromosome (that portion bearing $\mathrm{H}-\mathrm{Y}$ genes), and that presence of $\mathrm{H}-\mathrm{Y}$ antigen need not preclude fertility in a mammalian « female ».

Among goats there is a dominant autosomal gene $P$ (" polled ») which causes hornlessness. Goats heterozygous for polled $(P /+)$ are born without horns, although they are otherwise unaffected. $X X$ goats that are homozygous for polled $(P / P)$ are also hornless, as might be expected, but in addition they have testes or ovotestes and exhibit phenotypes ranging from hermaphroditic female to almost normal male (Soller ef al., 1969). These observations suggest that the polled gene or a closely linked gene acts as a recessive testis-determinant. We have studied a family of polled goats including a genetic female presumably homozygous for polled ( $X X, P / P)$. H-Y antigen was detected in the polled intersex goat, and in a second unrelated polled intersex goat. In this case there was a suggestion that cells from the P/P intersex goats absorbed less $\mathrm{H}$-Y antibody than cells from the father $(X Y, P /+)$, but the structure of the study did not allow us to determine whether this difference reflected decreased expression of $\mathrm{H}-\mathrm{Y}$ in the tissues of the intersex goats, or increased expression in the cells of the father. In any event these findings did show that presence of $\mathrm{H}-\mathrm{Y}$ antigen (like presence of testes or ovotestes) can be determined by « recessive » genes (Wachtel, Basrur and Koo, 1978).

Evidently recessive modes of sex determination are not limited to farm animals. Genealogical studies of a group of three $X X$ human males revealed a common forefather born in 1664 in southwest Finland. According to the pedigree, the sex-reversed condition in each of the three probands was caused by recessive testis-determining genes. (It would seem unlikely that the same rare syndrome should appear spontaneously three times in a single family.) But a recessive mode of sex-determination infers occurrence of sex determining genes in both father and mother. Accordingly the $X X$ males and their families were tested for $H-Y$ antigen. The three $X X$ males and their $X Y$ fathers were typed $\mathrm{H}-Y+_{-}$. In addition $\mathrm{H}-\mathrm{Y}$ antigens were present in the mothers of the $X X$ males, though perhaps not to the same extent as in normal $X Y$ male controls (de la Chapelle, Koo and Wachtel, 1978). It may be worth mentioning that despite expression of $\mathrm{H}-\mathrm{Y}$, there was no evidence of testicular differentiation or masculinization of secondary sex characteristics in any of the three mothers. In this respect the recessive modes of sex determination of goat and human are analogous, although we did not detect $\mathrm{H}-\mathrm{Y}$ antigen in the tissues of the mother of the polled goat. 


\section{A system of testis-determinants ?}

How can male sex-determining loci act as dominant genes in some cases, and as recessive genes in others? If we assume existence of a complex of $\mathrm{H}-\mathrm{Y}$ structural loci, then translocation could affect either a dominant or recessive system of testis determinants depending on the particular portion of $\mathrm{H}-\mathrm{Y}$ genes transferred. Say for example that the $\mathrm{Y}$-chromosome normally carries $\mathrm{H}-\mathrm{Y}$ genes $a, b, c, d$, e, and $f$. And say that abcd represent a minimal (threshold) requirement for testicular organogenesis, but that festicular organogenesis could be induced by genes ef in the homozygous state (or by a combination of $a b$ on one chromosome and $c d$ on another, etc.). It follows that Y-to-autosome (or Y-to-X) translocation of abcd would generate a dominant testisdeterminant (as in Sxr/- mice and Selden's dogs), and that Y-to-autosome or Y-to-X translocation of ef would generate a recessive testis-determinant (as in the polled goats or de la Chapelle's human family). This model predicts that some translocations could result in partially deleted $Y$-chromosomes (- . - , ef, for example) able to synthesize serologically detectable $H-Y$ antigens, but unable to sustain a program of normal testicular differentiation. (A need for distinct $H-Y$ genes as opposed to a system of $\mathrm{H}-\mathrm{Y}$ gene copies might be predicated on evidence for at least two different $\mathrm{H}-\mathrm{Y}$ antigens in the mouse ; see for example Melvold et al. (1977) and Hurme et al. (1978a and $b$ ).

Evidence for this model has been provided in at least one clinical case : an $X Y$ human female with several of the stigmata of Turner's syndrome including undifferentiated gonads. $\mathrm{H}-\mathrm{Y}$ was not detected in cultured skin fibroblasts, and blood leukocytes of this patient absorbed considerably less $\mathrm{H}-\mathrm{Y}$ antibody than blood leukocytes from normal $X Y$ males. Subsequent karyotypic analysis revealed a deletion of the small arm of the $Y$-chromosome ( $X Y^{-}{ }^{-}$) (the father's $Y$ was intact), observations favoring the view that both «Turner-suppressing " genes and a critical portion of testisdetermining $\mathrm{H}-\mathrm{Y}$ genes had been lost (Rosenfeld et al., 1978).

4th Workshop on " Development and maturation of the reproductive organs and functions " Luynes, France, octobre 1978.

Acknowledgements. - Supported in part by grants from the National Institules of Health : Al-11982, CA-08748, HD-00171, HD-10065.

Résumé. La présence de l'antigène $H-Y$ n'indique pas toujours la présence de testicules. Quand l'antigène H-Y ne se lie pas à son récepteur, la gonade indifférenciée de mammifère devient un ovaire. Dans l'espèce humaine, cet ovaire peut dégénérer, définissant ainsi le syndrome de « dysgénésie gonadique» $(46, X Y)$ chez des femmes phénotypiquement $\mathrm{H}-\mathrm{Y}^{+}$.

Nous avons décelé récemment l'antigène $H-Y$ chez des mâles $X X$ intersexués appartenant à une race de chèvres « sans corne » et dans une famille humaine chez trois hommes $X X$ récessivement déterminés ainsi que chez leurs mères ; ce fait nous conduit à penser que les loci $\mathrm{H}-\mathrm{Y}$ pourraient parfois intervenir comme des gènes récessifs. Ceci pourrait s'expliquer si les loci H-Y étaient constitués par un complexe de gènes induisant la différenciation du testicule. Une translocation pourrait donner lieu à des régulations 
dominantes ou récessives de la détermination du sexe mâle, selon la portion du complexe transférée. L'expression de l'antigène $\mathrm{H}-Y$ chez la femelle fertile n'est pas forcément en contradiction avec ce schéma car les spécificités antigéniques particulières décelées ne représentent pas nécessairement une partie fonctionnellement importante du complexe $\mathrm{H}-\mathrm{Y}$ intervenant dans la différenciation du testicule.

\section{References}

BENNETT D., MATHIESON B. J., SCHEID M., YANAGISAWA K., BOYSE E. A., WACHTEL S. S., CATTANACH B. M., 1977. Serological evidence for $\mathrm{H}-\mathrm{Y}$ antigen in $5 \times r, \mathrm{XX}$ sex-reversed phenotypic males. Nature, 265, 255-257.

DE LA CHAPELLE A., KOO G. C., WACHTEL S. S., 1978. Recessive sex-determining genes in human $X X$ male syndrome. Cell, 15, 837-842.

DORUS E., AMAROSE A. P., KOO G. C., WACHTEL S. S., 1977. Clinical, pathologic, and genetic findings in a case of 46, $X Y$ pure gonadal dysgenesis (Swyer's syndrome). Am. J. Obstet. Gynecol., 127, 829-831.

ESPINER E. A., VEALE A. M. O., SANDS V. E., FITZGERALD P. H., 1970. Familial syndrome of streak gonads and normal male karyotype in five phenotypic females. N. Engl. J. Med., 283, 6-11.

FREDGA K., GROPP A., WINKING H., FRANK F., 1977. A hypothesis explaining the exceptional sex ratio in the wood lemming (Myopus schisticolor). Hereditas, 85, 101-104.

GERMAN J., SIMPSON J. L., CHAGANTI R. S. K., SUMMIT R. L., REID L. B., MERKATZ I. R., 1978. Genetically determined sex-reversal in 46, XY humans. Science, 202, 53-56.

GOLDBERG E. H., BOYSE E. A., BENNETT D., SCHEID M., CARSWELL E. A., 1971. Serological demonstration of $\mathrm{H}-\mathrm{Y}$ (male) antigen on mouse sperm. Noture, 232, 478-480.

HURME M., CHANDLER P. R., HETHERINGTON C. M., SIMPSON E., 1978a. Cytotoxic T-cell responses to H-Y : correlation with the rejection of syngeneic male skin grafts. J. exp. Med., 147, 768-775.

HURME M., HETHERINGTON C. M., CHANDLER P. R., SIMPSON E., 1978b. Cytotoxic T-cell responses to $H-Y$ : mapping of the Ir genes. J. exp. Med., 147, 758-767.

JOST A., 1953. Problems of fetal endocrinology : the gonadal and hypophyseal hormones. Recent Prog. Horm. Res., 8, 379-418.

JOST A., 1961. The role of fetal hormones in prenatal development. Harvey Lectures, Series, 55, 201-226. Acad. Press, New York.

JOST A., 1970. Hormonal factors in the sex differentiation of the mammalian fœetus. Phil. Trans. roy. Soc. Lond. B, 259, 119-130.

KOO G. C., BOYSE E. A., WACHTEL S. S., 1977. Immunogenetic techniques and approaches in the study of sperm and testicular cell surface antigens, 73-84. In EDIDIN M., JOHNSON M. H., Immunobiology of gametes. Alden Press, Oxford.

KOO G. C., GOLDBERG C. L., 1978. A simplified technique for $\mathrm{H}-\mathrm{Y}$ typing. J. Immunol. Methods, 23, 197-201.

MELVOLD R. W., KOHN H. I., YERGANIAN G., FAWCETT D. W., 1977. Evidence suggesting the existence of two H-Y antigens in the mouse. Immunogenetics, 5, 33-41.

MULLER U., ASCHMONEIT 1., ZENZES M. T., WOLF U., 1978. Binding studies of H-Y antigen in rat tissues. Indications for a gonad specific receptor. Hum. Genet., 43, 151-157.

OHNO S., CHRISTIAN L. C., WACHTEL S. S., KOO G. C., 1976. Hormone-like role of H-Y antigen in bovine freemartin gonad. Nature, 261, 597-599.

OHNO S., CICCARESE S., NAGAI Y., WACHTEL S. S., 1978. H-Y antigen in testes of XX (BALB) XY (C3H) chimaeric male mouse. Arch. Androl., 1, 103-109.

OHNO S., NAGAI Y., CICCARESE S., 1978. Testicular cells lysostripped of $\mathrm{H}-\mathrm{Y}$ antigen organize ovarian follicle-like aggregates. Cytogenet. Cell Genet., 20, 351-364.

ROSENFELD R., LUZZATTI L., HINTZ R., MILLER O. J., KOO G. C., WACHTEL S. S., 1978. Studies of $\mathrm{H}-\mathrm{Y}$ antigen in a $46, X \mathrm{YP}^{-}$phenotypic female with Turner stigmata and undifferentiated gonads. Abstract 560. Pediatr. Res., 12, 457. 
SELDEN J. R., WACHTEL S. S., KOO G. C., HASKINS M. E., PATTERSON D. F., 1978. Genetic basic of $X X$ male syndrome and $X X$ true hermaphroditism : evidence in the dog. Science, 201, 644-646.

SILVERS W. K., WACHTEL S. S., 1977. H-Y antigen : behavior and function. Science, 195, 956-960.

SOLLER M., PADEH B., WYSOKI M., AYALON N., 1969. Cytogenetics of Saanen goats showing abnormal development of the reproductive tract associated with the dominant gene for polledness. Cytogenetics, 8, 51-67.

STERNBERG W. H., BARCLAY D. L., KLOEPFER W., 1968. Familial XY gonadal dysgenesis. $N$. Engl. J. Med., 278, 695-700.

WACHTEL S. S., BASRUR P., KOO G. C., 1978. Recessive male-determining genes. Cell, 15, 279 281.

WACHTEL S. S., OHNO S., KOO G. C., BOYSE E. A., 1975. Possible role for H-Y antigen in the primary determination of sex. Nature, 257, 235-236.

WILSON J. D., 1978. Sexual differentiation. Ann. Rev. Physiol., 40, 279-306.

ZENZES M. T., WOLF U., GUNTHER E., ENGEL W., 1978. Studies on the function of H-Y antigen : dissociation and reorganization experiments on rat gonadal tissue. Cylogenet. Cell Genet., 20, 365-372. 